\title{
Decreased rhizodeposition, but increased microbial carbon stabilization with soil depth down to $3.6 \mathrm{~m}$
}

\author{
Leanne Peixoto $^{\text {a, *, Lars Elsgaard }}{ }^{\text {a,e }}$, Jim Rasmussen ${ }^{\text {a }}$, Yakov Kuzyakov ${ }^{\text {b,c }}$, Callum C. Banfield ${ }^{\mathrm{d}}$, \\ Michaela A. Dippold ${ }^{\mathrm{d}}$, Jørgen E. Olesen ${ }^{\text {a, e }}$ \\ ${ }^{a}$ Department of Agroecology, Aarhus University, Blichers Allé 20, 8830 Tjele, Denmark \\ ${ }^{\mathrm{b}}$ Division Agricultural Soil Science, University of Goettingen, Goettingen, Germany \\ ${ }^{\mathrm{c}}$ Agro-Technological Institute, RUDN University, 117198 Moscow, Russia \\ ${ }^{\mathrm{d}}$ Division Biogeochemistry of Agroecosystems, University of Goettingen, Goettingen, Germany \\ ${ }^{\mathrm{e}}$ ICLIMATE Interdisciplinary Centre for Climate Change, Aarhus University, Frederiksborgvej 399, 4000 Roskilde, Denmark
}

\section{A R T I C L E I N F O}

\section{Keywords:}

Carbon deposition

Carbon stabilization

Microbial necromass

Deep subsoil

Deep-rooted crops

Compound-specific stable isotope probing

\begin{abstract}
A B S T R A C T
Despite the importance of subsoil carbon (C) deposition by deep-rooted crops in mitigating climate change and maintaining soil health, the quantification of root $\mathrm{C}$ input and its microbial utilization and stabilization below 1 $\mathrm{m}$ depth remains unexplored. We studied $\mathrm{C}$ input by three perennial deep-rooted plants (lucerne, kernza, and rosinweed) grown in a unique 4-m deep RootTower facility. ${ }^{13} \mathrm{C}$ multiple pulse labeling was applied to trace $\mathrm{C}$ flows in roots, rhizodeposition, and soil as well as ${ }^{13} \mathrm{C}$ incorporation into microbial groups by phospholipid fatty acids and the long-term stabilization of microbial residues by amino sugars. The ratio of rhizodeposited ${ }^{13} \mathrm{C}$ in the PLFA and amino sugar pools was used to compare the relative microbial stability of rhizodeposited C across depths and plant species. Belowground $\mathrm{C}$ allocation between roots, rhizodeposits, and living and dead microorganisms indicated depth dependent plant investment. Rhizodeposition as a fraction of the total belowground C input declined from the topsoil $(0-25 \mathrm{~cm})$ to the deepest layer $(360 \mathrm{~cm})$, i.e., from $35 \%, 45 \%$, and $36 \%-8.0 \%$, $2.5 \%$, and $2.7 \%$ for lucerne, kernza, and rosinweed, respectively, where lucerne had greater $\mathrm{C}$ input than the other species between 340 and $360 \mathrm{~cm}$. The relative microbial stabilization of rhizodeposits in the subsoil across all species showed a dominance of recently assimilated $\mathrm{C}$ in microbial necromass, thus indicating a higher microbial stabilization of rhizodeposited $\mathrm{C}$ with depth. In conclusion, we traced photosynthates down to $3.6 \mathrm{~m}$ soil depth and showed that even relatively small $\mathrm{C}$ amounts allocated to deep soil layers will become microbially stabilized. Thus, deep-rooted crops, in particular lucerne are important for stabilization and storage of $\mathrm{C}$ over long time scales in deep soil.
\end{abstract}

\section{Introduction}

The ability of soils to store organic carbon (OC) holds the potential to mitigate climate change by adoption of management measures that increase OC deposition while concurrently reducing its decomposition (Stockmann et al., 2013; Lal et al., 2015). Recent initiatives have focused on increasing OC contents in topsoil, while the role of OC increase in subsoils, and especially deep subsoils below $1 \mathrm{~m}$, is far less explored. Yet, this represents a promising climate mitigation option, because of expected slow decomposition and long-term stabilization of OC in deep subsoils as compared with topsoil owing to contrasting biogeochemical conditions with depth (Salomé et al., 2010; Sanaullah et al., 2011). An operational biological route of introducing OC compounds into deep subsoils is via the growth of deep-rooted perennial crops (Kell, 2011, 2012).

Despite the potential importance of subsoil OC accumulation, the quantity of rhizodeposition and root carbon (C) input from deep-rooted crops below $1 \mathrm{~m}$ remains largely unknown. Estimates show that the proportion of recently assimilated $\mathrm{C}$ allocated belowground as rhizodeposition accounts for $3 \%$ for crops and $5 \%$ for grasses, whereas $10 \%$ of $\mathrm{C}$ in crops and $16 \%$ in grasses reside in the roots (reviewed by Pausch and Kuzyakov, 2018). However, these assessments were all done for the topsoil $(0-30 \mathrm{~cm})$, where microbial activity is high and nutrient availability is generally not a constraint as compared to deeper soils. The

\footnotetext{
* Corresponding author.

E-mail address: leanne.peixoto@agro.au.dk (L. Peixoto).
} 
question remains if deep-rooting crops would allocate substantial amounts of $C$ to deep subsoil that may trigger $C$ sequestering processes in this $\mathrm{C}$ depleted environment, so that considering solely $\mathrm{C}$ allocation to topsoil will strongly underestimate the belowground $\mathrm{C}$ allocation.

Rhizodeposits are used by rhizomicrobial communities to fuel metabolic processes and build up microbial biomass (e.g., Kindler et al., 2009), which eventually transforms to necromass and contributes to soil organic carbon (SOC) stabilization (Liang et al., 2011; Bai et al., 2017). The importance of this route of stabilization depends on differences in C use efficiency among microbial groups, such as fungi and bacteria, as well as the complexity and longevity notably of their cell wall constituents (Bell et al., 2003; Dungait et al., 2011; Gunina et al., 2017). As such, it is crucial to quantify the proportion of rhizodeposited C that will be incorporated into both living and dead bacterial and fungal pools, and such quantification can be achieved by compound-specific biomarkers (Kindler et al., 2009; Liang et al., 2011; Joergensen, 2018). Microbial cell constituents such as phospholipid fatty acids (PLFA) (Kindler et al., 2009), and amino sugars (Amelung et al., 2001; Liang et al., 2011; Joergensen, 2018) comprise key compound-specific biomarkers that indicate origins and contributions of microbial-derived metabolites to SOC (Amelung et al., 2001; Gunina et al., 2017; Liang et al., 2017).

PLFAs are components of microbial cell membranes, but rapidly decompose upon cell death, thereby providing a signature of the living microbial biomass and short-term contribution to SOC (Frostegård et al., 1993; Frostegård and Bååth, 1996; Kindler et al., 2009). Amino sugars are derived predominately from senesced bacterial and fungal cell walls (i.e., necromass) that are highly stable in soils and as such, considered a highly stabilized $\mathrm{C}$ form contributing to the medium and long-term SOC storage (Amelung et al., 2001). Bacterial cell walls contain $\mathrm{N}$-acetylglucosamine (GlcN) and $N$-acetylmuramic acid (MurN) as the dominant amino sugars, whereas fungal cell walls contain only GlcN. In addition, $N$-acetylgalactosamine (GalN) and mannosamine (ManN) have been quantified in soils, but they originate from both bacteria and fungi as potential extracellular polymeric substances (Amelung et al., 2001; Joergensen et al., 2018).

Improved understanding of the partitioning of rhizodeposited $\mathrm{C}$ into microbial pools (within both the living and the dead pools) in conjunction with the quantification of $\mathrm{C}$ input from deep-rooted perennial crops below $1 \mathrm{~m}$ soil depth remains vital for addressing the potential of deep-rooted crops in depositing $\mathrm{C}$ in soils. Further, the current SOC paradigm indicates that nearly $50 \%$ of SOC is derived from microbial necromass, but quantitative assessments of the microbial stabilization of rhizodeposited C in subsoils are lacking (e.g., Liang et al., 2019a). The overall objective of this study was to examine the efficacy of deep-rooting crops in storing $\mathrm{C}$ in deep subsoils as a climate mitigation measure. This was based on the underlying hypothesis that deep-rooted crops will increase the $\mathrm{C}$ input to deep soil layers and that crops with low $\mathrm{C} / \mathrm{N}$ ratio, like lucerne, will enhance microbial $\mathrm{C}$ turnover and thus stabilization in deep soil, as $\mathrm{N}$ availability has been found to limit microbial activity in deep subsoils (Liang et al., 2018, 2019b). This objective was addressed through the quantification of $\mathrm{C}$ input by roots and rhizodeposition down to soil depths of $3.6 \mathrm{~m}$ across three distinct deep-rooted perennial plant species. These plant species vary in relation to their rooting system (tap-rooted vs. fibrous) and $\mathrm{N}_{2}$ fixation capacity (legume vs. non-legumes). Deposition of $\mathrm{C}$ from recent photosynthates was traced using ${ }^{13} \mathrm{C}$ multiple pulse labeling during July to September 2018. Based on the recovery of ${ }^{13} \mathrm{C}$ in PLFAs and amino sugars, we examined the relative microbial stabilization of rhizodeposited $\mathrm{C}$ within the living and dead microbial pools to indicate the relative stabilization of rhizodeposited $\mathrm{C}$ into the microbial necromass across depths and plant species.

\section{Materials and methods}

\subsection{Site description}

The experiment was performed in an outdoor RootTower facility at University of Copenhagen, Denmark (Rasmussen et al., 2020; Thorup-Kristensen et al., 2020a). The facility consists of 4-m high rectangular RootTowers $(1.2 \times 0.6 \mathrm{~m})$ filled with topsoil $(0-25 \mathrm{~cm})$, and two subsoil layers $(25-200 \mathrm{~cm}$ and $200-400 \mathrm{~cm})$. The topsoil was a mixture of a clayey loam and sandy loam topsoil from the University's experimental farm in Taastrup $\left(55^{\circ} 40^{\prime} 08.5^{\prime \prime} \mathrm{N}, 12^{\circ} 18^{\prime} 19.4^{\prime \prime} \mathrm{E}\right)$. The clayey loam subsoils originated from an arable field at Store Havelse, Denmark $\left(55^{\circ} 89^{\prime} 83.9^{\prime \prime} \mathrm{N}, 12^{\circ} 06^{\prime} 52.8^{\prime \prime} \mathrm{E}\right)$. Both topsoil and subsoils were from soils classified as Luvisols according to the World Reference Base for Soil Resources (IUSS Working Group WRB, 2015). Different sources of topsoil and subsoil were used for logistical reasons, but both sampling sites represented Luvisols developed from similar parent materials. Filling of the RootTowers occurred in May 2016, where soil from the individual compartments was added in $0.15 \mathrm{~m}$ portions and compacted with a steel piston to $1.55-1.65 \mathrm{~g} \mathrm{~cm}^{-3}$, which was similar to the bulk density under field conditions. Details of the RootTowers and the soil types are presented by Rasmussen et al. (2020) and shown in Supplemental Table 1.

Three perennial species: lucerne (Medicago sativa L.; Family: Fabaceae), rosinweed (Silphium integrifolium; Family: Asteraceae), and kernza (Thinopyrum intermedium; Family: Poaceae) were each grown in triplicate RootTowers. All plants were initially transplanted as seedlings to the RootTowers in July 2016 (three to five plants per RootTower), and subsequently harvested each year in July and at the end of the growing season (September). These perennial plants were therefore in their second year of growth during the experiment in 2018. Each RootTower was fertilized with the equivalent of $100 \mathrm{~kg} \mathrm{~N} \mathrm{ha}^{-1}$ in April and $75 \mathrm{~kg} \mathrm{~N}$ $\mathrm{ha}^{-1}$ in July of 2018, except for lucerne that was kept unfertilized. Each RootTower was rainfed and supplemented with a drip irrigation system $\left(14 \mathrm{~mm} \mathrm{~h}^{-1}\right)$ depending on the volumetric water content of the soil measured by time-domain reflectometry (TDR) sensors (TDR-315/TDR315 L, Acclima Inc., Meridian, Idaho) placed at four depths. A wick system at the bottom of the soil column allowed free drainage. Further, the entire depth profile of each RootTower $(0-4 \mathrm{~m})$ could be accessed through a system of 20 removable panels each of ca. $20 \mathrm{~cm}$ height (Rasmussen et al., 2020).

\subsection{Leaf ${ }^{13} \mathrm{C}$ labeling}

To determine the net rhizodeposition among the deep-rooted crops, ${ }^{13} \mathrm{C}$ leaf-labeling was performed twice a week from mid-July to midSeptember 2018, which represents the second half of the growing season (Rasmussen et al., 2013). For lucerne and kernza, five un-cut mature leaves were inserted into 2-mL Eppendorf tubes containing $1 \mathrm{~mL}$ of the labeling solution of $\mathrm{NaOH}\left(10^{-5} \mathrm{M}\right)$ with ${ }^{13} \mathrm{C}$-labeled bicarbonate (99 atom\%, $0.01 \mathrm{M}$ ). For rosinweed, three tip-cut mature leaves per plant were inserted into $50-\mathrm{mL}$ tubes containing $20 \mathrm{~mL}$ of the labeling solution. The tubes were sealed with inert plastic material (Teroson RB) to avoid water entering the solution or evaporative losses. All plants were labeled across the three replicate RootTowers. Following removal of the tubes, the labeled leaves were cut from the plant and removed, to prevent the incorporation of labeled senesced leaf material into the soil.

\subsection{Root and soil sampling}

Soil samples (and associated roots) were collected horizontally from seven depths: 0-25 cm, 40-60 cm, 100-120 cm, 160-180 cm, 220-240 $\mathrm{cm}, 280-300 \mathrm{~cm}$, and $340-360 \mathrm{~cm}$ (using a soil auger; $250 \mathrm{~mm}$ length $\mathrm{x}$ $70 \mathrm{~mm}$ diameter) from each of the RootTowers and used in the calculation of root $\mathrm{C}$ and net rhizodeposition. Specifically, four depths (i.e., $0-25,100-120,220-240$, and $340-360 \mathrm{~cm}$ ) were used for biomarker 
analyses and ${ }^{13} \mathrm{C}$ stable isotope probing. Sampling was performed prior to labeling to obtain unlabeled samples (i.e., natural ${ }^{13} \mathrm{C}$ abundance) and again two days after the last labeling period (mid-September 2018). Specifically, two or three soil samples were taken per depth and stored at $2-5{ }^{\circ} \mathrm{C}$ until processing within two weeks. Only two samples were taken at the two depths where there was a risk of damaging installed TDR sensors. For every sample removed, the RootTowers were carefully repacked with the same soil as used in the original filling in 2016. Subsequent soil sampling always targeted the original soil (and not the repacked soil) in the RootTowers.

Roots, bulk soil and rhizosphere soil (defined as soil adhering to the roots) were separated according to Pedersen et al. (2019) by sequential sieving of the soil with finer mesh sizes to $1 \mathrm{~mm}$. The use of the $1 \mathrm{~mm}$ sieve aided in the removal of fine root fragments from the soil samples. Both bulk and rhizosphere soil were used for quantifying the net rhizodeposition and rhizosphere soil was used exclusively for PLFA and amino sugar biomarkers and ${ }^{13} \mathrm{C}$ stable isotope probing analyses.

\subsection{Determination of ${ }^{13} \mathrm{C}$ enrichment, and $C$ and $N$ quantity}

The isolated portions of soil and root samples were each mixed per depth from each of the triplicate RootTowers, and homogenized samples were freeze-dried (except soils for PLFA analyses that were stored at $-20{ }^{\circ} \mathrm{C}$ ) and ground in a ball-mill to a fine powder.

Carbonates were removed from the soils using hydrochloric acid $(\mathrm{HCl})$ fumigation to avoid interference in $\delta^{13} \mathrm{C}$ analyses (Ramnarine et al., 2011). This process removed any ${ }^{13} \mathrm{C}$ incorporated in carbonates and allowed us to focus on the $\mathrm{OC}$ fraction in the determination of root $\mathrm{C}$ input. Soil samples were placed in a desiccator with a beaker of $100 \mathrm{~mL}$ of $11 \mathrm{M} \mathrm{HCl}$. After three days, the beaker content was replaced with $\mathrm{NaOH}$ pellets to remove residual $\mathrm{HCl}$ vapor and dry the samples in the desiccator for one week. Samples were weighed before and after $\mathrm{HCl}$ fumigation to account for the formation of chlorides and the loss of carbonates (Ramnarine et al., 2011).

For total $\mathrm{C}, \mathrm{N}$ and ${ }^{13} \mathrm{C}$ determination, $20-30 \mathrm{mg}$ of soil sample and $\sim 5 \mathrm{mg}$ of root sample were weighed in tin capsules and measured with a FLASH 2000 CHNS/O Elemental Analyzer (Thermo Fisher Scientific, Cambridge, UK) combined to a DELTA V Advantage isotope ratio mass spectrometer via a ConFlo III interface (Thermo Fisher Scientific, Bremen, Germany) at the Centre for Stable Isotope Research and Analysis (Georg August University Goettingen, Goettingen, Germany). All reported $\delta^{13} \mathrm{C}$ values are standardized to the Vienna PeeDee Belemnite (VPDB) international isotope standard.

\subsection{Calculation of root $C$ and net rhizodeposition}

The amount of root C ( $\mathrm{g} \mathrm{C} \mathrm{kg}^{-1}$ dry weight ( $\mathrm{dw}$ ) soil) was calculated as described by Hafner and Kuzyakov (2016). To determine the proportion of rhizodeposition, the tracer mass balance approach based on the C lost via rhizodeposition (\%ClvR) was used as follows (Rasmussen et al., 2019):

$\% \mathrm{ClvR}=\frac{{ }^{13} \mathrm{C} \text { Soil }}{{ }^{13} \mathrm{C} \mathrm{Soil}+{ }^{13} \mathrm{C} \text { Root }} \times 100$

The ${ }^{13} \mathrm{C}$ soil pool was calculated by multiplying the ${ }^{13} \mathrm{C}$ atom $\%$ excess of the soil by the quantity of $\mathrm{C}$ in the soil sample (for both bulk and rhizosphere soil), and the ${ }^{13} \mathrm{C}$ root pool was calculated by multiplying the ${ }^{13} \mathrm{C}$ atom $\%$ excess of the roots by the quantity of $\mathrm{C}$ in the root sample. Furthermore, the quantity or the mass of $\mathrm{C}$ lost via rhizodeposition was determined as (\%ClvR $\mathrm{x}$ root $\mathrm{C}$ content)/(100-\%ClvR).

\subsection{Phospholipid fatty acids and ${ }^{13}$ C PLFA stable isotope probing}

The identification and quantification of PLFAs were conducted as previously described by Petersen et al. (2002). Lipids were extracted from $2 \mathrm{~g}$ of rhizosphere soil (stored at $-20^{\circ} \mathrm{C}$ for three weeks). Samples were analyzed from each plant species at four depths (0-25, 100-120, 220-240 and 340-360 cm) including unlabeled control samples, corresponding to each labeled sample taken at the same soil depth. To obtain a purified lipid extract, a modified one-phase Bligh-Dyer extraction (Bligh and Dyer, 1959) using chloroform, methanol and phosphate buffer was conducted using subsequent lipid fractionation via a solid-phase extraction based on $100 \mathrm{mg}$ silica columns with a methanol elution to obtain phospholipids. The fractionation was followed by conversion to fatty acid methyl esters (i.e., FAMEs) via an alkaline trans-esterification; FAMEs were eventually diluted in $100 \mu \mathrm{L}$ hexane and analyzed via gas-chromatography-combustion-isotopic ratio mass spectrometry (GC-C-IRMS) at the Department of Biology, Lund University, Sweden. Quantification was conducted relative to internal standards of nonadecanoic acid (C19:0) and tridecanoic acid (C13:0). PLFA biomarkers were selected according to Frostegård et al. (1993) and Fierer et al. (2003) with PLFA nomenclature as described by Frostegård et al. (1993) (Supplemental Table 2). A proxy of the living microbial biomass was estimated as the sum of all PLFAs, which is based on the assumption of a direct relation between PLFAs and microbial biomass.

To determine the $\delta^{13} \mathrm{C}$ PLFA signatures, all raw $\delta^{13} \mathrm{C}$ values were corrected for the addition of a single carbon atom during the esterification process (Kušliene et al., 2014) as well as corrected for drift and amount dependence as described by Dippold et al. (2014). Following this correction, the ${ }^{13} \mathrm{C}$ excess for each PLFA was determined as the difference between the ${ }^{13} \mathrm{C}$ of the labeled and unlabeled PLFA; the ${ }^{13} \mathrm{C}$ excess was multiplied by the $C$ content of the PLFA to determine the amount of ${ }^{13} \mathrm{C}$ incorporated into each PLFA.

\subsection{Amino sugars and ${ }^{13} \mathrm{C}$ amino sugar stable isotope probing}

The extraction of amino sugars was done according to a modified protocol by Zhang and Amelung (1996) using the same soil samples as for PLFA analyses. Amino sugars were extracted from $3 \mathrm{~g}$ of freeze-dried rhizosphere soil, which underwent a pre-treatment due to carbonate contents of the soil buffering the acid hydrolysis. The pre-treatment consisted of shaking the soil in $30 \mathrm{~mL}$ of $1 \mathrm{M} \mathrm{HCl}$ for $3 \mathrm{~h}$ followed by $15 \mathrm{~min}$ centrifugation at $2000 \mathrm{rpm}$. After centrifugation, $25 \mathrm{~mL}$ of the residual $\mathrm{HCl}$ was replaced by $30 \mathrm{~mL}$ of $6 \mathrm{M} \mathrm{HCl}$ and the sample was hydrolyzed for $8 \mathrm{~h}$ at $105{ }^{\circ} \mathrm{C}$. Following hydrolysis, soil samples were filtered through glass fiber filters (Whatman GF6, GE Healthcare, Pittsburgh, PA, USA) under vacuum and $\mathrm{HCl}$ was removed via rotary evaporation at $45{ }^{\circ} \mathrm{C}$ to dry the filtrate. The filtrate was then re-suspended with Millipore ${ }^{\mathrm{TM}}$ water, and $\mathrm{pH}$-adjusted to 6.6-6.8 with $\mathrm{KOH}$ for iron precipitation, and centrifuged at $4000 \mathrm{rpm}$ for $15 \mathrm{~min}$ to remove the iron precipitates. The residue was frozen at $-20^{\circ} \mathrm{C}$ and then freeze-dried to remove any remaining liquid overnight. The residue was dissolved in methanol and centrifuged (4000 rpm, $15 \mathrm{~min}$ ) to remove salts. The remaining residue was transferred to 5 - $\mathrm{mL}$ reaction vials for methanol evaporation under nitrogen $\left(\mathrm{N}_{2}\right)$ flow. Prior to derivatization, $25 \mu \mathrm{L}$ of methylglucamine (MeGlcN) $\left(1 \mathrm{mg} \mathrm{mL}^{-1}\right)$ was added as the internal standard to each of the samples and used in the quantification of recovery of the amino sugars. The derivatization of amino sugars into aldononitrile acetates was conducted as described by Zhang and Amelung (1996). The residues were then dissolved in $185 \mu \mathrm{L}$ of ethyl acetate-hexane $(1: 1, v / v)$, and $15 \mu \mathrm{L}$ of a second internal standard, tridecanoic acid methyl ester $\left(1 \mathrm{mg} \mathrm{mL}^{-1}\right)$, were added to the samples.

In addition, an external standard stock solution was prepared containing the amino sugars: GlcN $\left(2 \mathrm{mg} \mathrm{mL}^{-1}\right)$, GalN $\left(2 \mathrm{mg} \mathrm{mL}^{-1}\right)$, MurN $\left(1 \mathrm{mg} \mathrm{mL}^{-1}\right)$, ManN ( $\left.2 \mathrm{mg} \mathrm{mL}^{-1}\right)$, and MeGlcN $\left(1 \mathrm{mg} \mathrm{mL}^{-1}\right)$, which were derivatized and analyzed with the samples. All aldononitrile acetate derivatives were measured using an Agilent 7890 A GC coupled to an Agilent 7000 A triple quadrupole mass spectrometer (Agilent, Waldbronn, Germany) with injection amount, column used, and additional parameter settings as described by Banfield et al. (2017).

The sum of GlcN, MurN, GalN and ManN was used as an indicator for the total amino sugar abundance. As both bacteria and fungi produce 
GalN and ManN (Amelung et al., 2001; Glaser et al., 2004; Engelking et al., 2007), these were analyzed only for total amino sugar abundance. MurN was used as a specific biomarker for bacterial amino sugars, and fungal GlcN was used as a specific biomarker for fungal amino sugars following a correction for bacterial contribution to GlcN based on the assumed molar ratio of bacterial MurN:GlcN as 1:2 (Engelking et al., 2007), and calculated according to Faust et al. (2017). The fungal GlcN: MurN ratio was used to determine the relative contribution of bacteria and fungi to SOC formation (e.g., Amelung et al., 2001).

To determine the ${ }^{13} \mathrm{C}$ enrichment of the amino sugars, all raw $\delta^{13} \mathrm{C}$ values were measured using a Delta V Advantage isotope ratio mass spectrometer via a ConFlo III interface (Thermo Fisher Scientific, Bremen, Germany). Chromatogram peaks specific to the amino sugar of interest were integrated using Isodat v. 3.0 (Thermo Fisher Scientific), and measured $\delta^{13} \mathrm{C}$ values were corrected for amount (area) dependence, offset, and the additional $\mathrm{C}$ atoms added during the derivatization reaction according to Glaser and Gross (2005) and Dippold et al. (2014). Furthermore, to determine the ${ }^{13} \mathrm{C}$ enrichment of the amino sugars following corrections, the ${ }^{13} \mathrm{C}$ excess for each amino sugar was determined as the difference between the ${ }^{13} \mathrm{C}$ of the labeled and unlabeled amino sugar and multiplied by the $\mathrm{C}$ content of the amino sugar. As the ${ }^{13} \mathrm{C}$ incorporation was only detected in GlcN and GalN, the ${ }^{13} \mathrm{C}$ incorporation in these amino sugars represented the total incorporation within the amino sugars.

\subsection{Partitioning of rhizodeposited $C$ in PLFA and amino sugar pools and} relative microbial stabilization

To quantify the relative proportion of rhizodeposited $\mathrm{C}$ incorporated into living microbial biomass (based on PLFAs) and microbial necromass (based on amino sugars) the partitioning of $\mathrm{C}$ derived from rhizodeposition into PLFA and amino sugar (AS) pools were calculated as follows:

Rhizodeposited C in PLFA $(\%)=\frac{{ }^{13} \text { C PLFA }}{{ }^{13} \text { C rhizosphere Soil }} \times 100$

Rhizodeposited C in AS (\%) $=\frac{{ }^{13} \text { C AS }}{{ }^{13} \text { C rhizosphere Soil }} \times 100$

where the ${ }^{13} \mathrm{C}$ PLFA (g ${ }^{13} \mathrm{C}$ PLFA g ${ }^{-1} \mathrm{dw}$ soil) and ${ }^{13} \mathrm{C}$ AS $\left(\mathrm{g}{ }^{13} \mathrm{C} \mathrm{AS} \mathrm{g}{ }^{-1}\right.$ $\mathrm{dw}$ soil) were determined as described in sections 2.6 and 2.7 , and ${ }^{13} \mathrm{C}$ rhizosphere soil ( ${ }^{13} \mathrm{C} \mathrm{g}^{-1} \mathrm{dw}$ soil) was determined as described in section 2.5 .

The relative amount of rhizodeposited ${ }^{13} \mathrm{C}$ in the PLFA and amino sugar pools was used to obtain an indication of the relative microbial stabilization of rhizodeposited $\mathrm{C}$ into the microbial necromass. PLFAs are present in the living microbial biomass and amino sugars are present predominately as necromass (Amelung et al., 2001; Kindler et al., 2009). The underlying assumption is that the ${ }^{13} \mathrm{C}$ incorporation into the amino sugar pool indicates the build-up of microbial tissue, which becomes stabilized as it is not immediately exposed to degradation as is the PLFAs (Amelung et al., 2001). Due to a low content of bacterial amino sugars, especially in the lower soil depths, we based our calculations of microbial stabilization on the total ${ }^{13} \mathrm{C}$ incorporation in PLFAs and amino sugars. Since PLFAs and amino sugars contain different $\mathrm{C}$ amounts in individual biomarkers we used the average weighted ${ }^{13} \mathrm{C}$ atom $\%$ excess of the PLFAs and amino sugars for the calculations. Further, it is known that ${ }^{13} \mathrm{C}$ is initially incorporated into the PLFA pool with a time lag in the ${ }^{13} \mathrm{C}$ incorporation into the amino sugar pool (Gunina et al., 2017). Hence, to make the relative microbial stabilization calculation independent of time, the sampling should not occur immediately after the first ${ }^{13} \mathrm{C}$ pulse labeling and the use of multiple pulses or continuous labeling is essential. Thus, by using the weighted ${ }^{13} \mathrm{C}$ atom $\%$ excess the calculation is standardized by the amount of $\mathrm{C}$ in PLFAs and amino sugars, respectively. The relative microbial stabilization is calculated as the $\log$ (used to transform the data to have values around 0 ) of the ${ }^{13} \mathrm{C}$ enrichment of the living and dead microbial necromass (the weighted ${ }^{13} \mathrm{C}$ atom\% excess in amino sugars) divided by the ${ }^{13} \mathrm{C}$ enrichment of the living microbial biomass (the weighted ${ }^{13} \mathrm{C}$ atom $\%$ excess in PLFA):

Relative microbial stabilization $=\log \frac{\text { Average weighted }{ }^{13} \text { Catom\% excess AS }}{\text { Average weighted }{ }^{13} \text { Catom\% excess PLFA }}$

where the average weighted ${ }^{13} \mathrm{C}$ atom $\%$ excess of each pool (PLFAs and amino sugars, AS) is the sum of the ${ }^{13} \mathrm{C}$ incorporated into PLFAs or amino sugars divided by the sum of the $\mathrm{C}$ content of the respective PLFA or amino sugar pools. The log transformation means that values $<0$ will be dominated by $\mathrm{C}$ allocated into living microbial biomass being a temporary $\mathrm{C}$ pool, whereas values $>0$ will reflect $\mathrm{C}$ allocated into microbial necromass, and thus be indicative of a high $\mathrm{C}$ stabilization potential. The relative microbial stabilization can be used to compare the importance of living microbial biomass versus dead microbial necromass among treatments (i.e., across different depths and plant species), but does not signify the absolute stability of rhizodeposition or SOC.

\subsection{Statistical analysis}

Analyses of variance (ANOVA) were conducted to test the effects of depth and plant species on each of the dependent variables. All microbial results are based on the rhizosphere soil dataset. Subsequent pairwise comparisons of the means were conducted using the Tukey post hoc test. Data were log-transformed (when required) to achieve homogeneity of variances and normality, which were confirmed for all comparisons using the Fligner-Killeen test of homogeneity of variances (Conover et al., 1981) and the Shapiro-Wilk test of normality (Royston, 1982). Significance testing was conducted at $p<0.05$. All statistical analyses were conducted in RStudio (R Core Team, 2018).

\section{Results}

\subsection{Belowground C investment}

The root $\mathrm{C}$ declined with depth across all plant species (Fig. 1; Supplemental Table 3). On average, the root $C$ across depths ranged from 90 to $820,30-680$, and $70-570 \mathrm{mg} \mathrm{C} \mathrm{kg}^{-1} \mathrm{dw}$ soil for lucerne, kernza, and rosinweed, respectively. Among species, lucerne had a higher root $\mathrm{C}$ than kernza and rosinweed between $100-120 \mathrm{~cm}$ and $340-360 \mathrm{~cm}$.

The net rhizodeposition was highest in the topsoil, and declined with depth (Fig. 1). The rhizodeposition expressed as \%ClvR declined from $35 \%, 45 \%$, and $36 \%$ of the total C input in the topsoil layer to $8.0 \%$, $2.5 \%$, and $2.7 \%$ in the deepest soil layer (i.e., $340-360 \mathrm{~cm}$ ) for lucerne, kernza, and rosinweed, respectively (Fig. 2). This corresponded to 5-790, 0.5-850, and 2-400 mg C kg ${ }^{-1} \mathrm{dw}$ soil for lucerne, kernza, and rosinweed from $360 \mathrm{~cm}$ to the topsoil (Fig. 1; Supplemental Table 3). The net rhizodeposition of both kernza and lucerne were higher than of rosinweed at $220-240 \mathrm{~cm}$, and highest for lucerne at $340-360 \mathrm{~cm}$ (Fig. 1; Supplemental Table 3).

\subsection{Bacterial and fungal PLFAs and amino sugars}

The living microbial biomass (based on total PLFAs) and ${ }^{13} \mathrm{C}$ incorporation into total PLFAs generally declined with depth and differed among plant species within the topsoil and at 100-120 cm (Fig. 3, Supplemental Figure 1). The bacteria/fungi PLFA ratio was 20-100 fold higher in topsoil than in subsoil and decreased systematically with depth for all species (Supplemental Figure 2). Within the topsoil, lucerne plots had a greater bacterial and fungal PLFA content and generally had a higher living microbial biomass and ${ }^{13} \mathrm{C}$ incorporation into PLFAs than found in the kernza and rosinweed plots (Fig. 3, Supplemental Figure 2). In the deep subsoil, kernza had a higher bacteria/fungi PLFA ratio as compared to rosinweed at 100-360 cm with marginal variation between kernza and lucerne between depths (Supplemental Figure 2). 


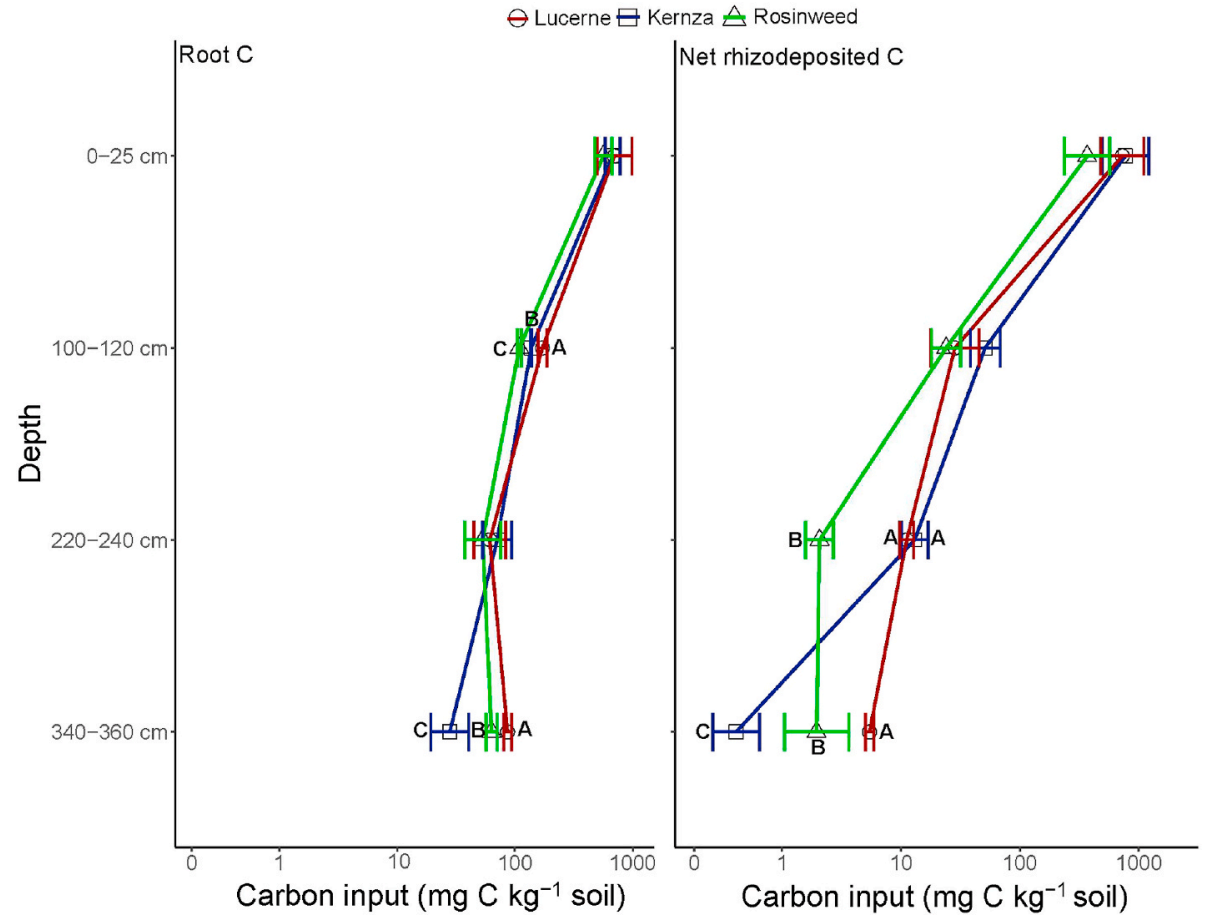

Fig. 1. Input of root C (left) and net rhizodeposited C (right) from lucerne, kernza, and rosinweed across four depth intervals: 0-25, 100-120, 220-240 and 340-360 $\mathrm{cm}$. Statistically significant differences $(p<0.05)$ between each species for each depth are indicated by different letters for both the root $\mathrm{C}$ and net rhizodeposited C. Relative standard errors (symmetric error bars) are shown on the logarithmic plot.

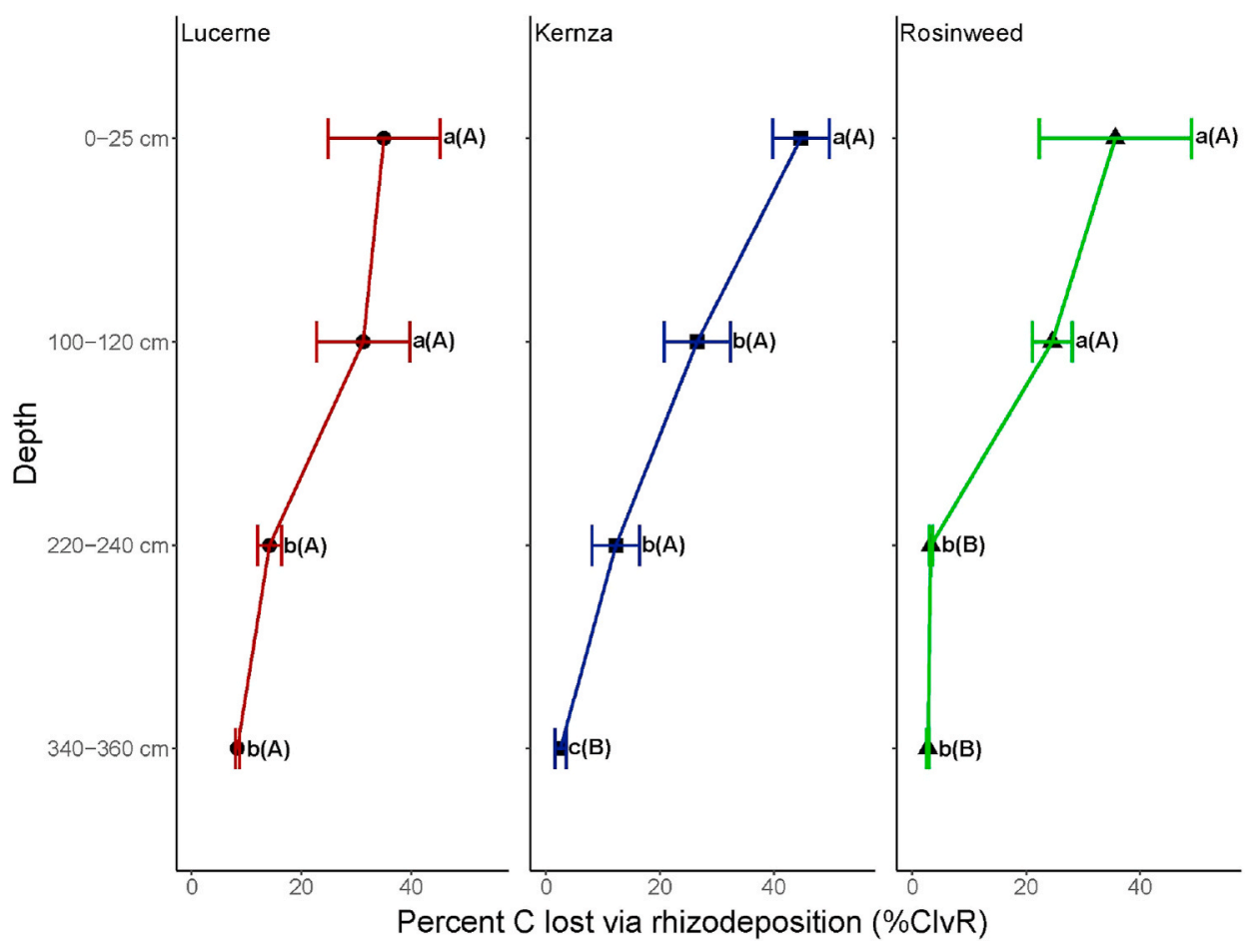

Fig. 2. Net rhizodeposition expressed as percent $C$ lost via rhizodeposition (\%ClvR) across four depth intervals: 0-25, 100-120, 220-240 and 340-360 cm for lucerne, kernza, and rosinweed. Different letters indicate statistically significant differences $(p<0.05)$ between the \%ClvR among the depths for each plant species (lower case letters) and between plant species for each depth (upper case letters).

The amino sugar abundance generally declined with depth across all plant species (Fig. 3). The same pattern was seen with the formation of new microbial residues, based on the ${ }^{13} \mathrm{C}$ incorporation of amino sugars (Supplemental Figure 3). There was no effect of plant species on the total amino sugar abundance and ${ }^{13} \mathrm{C}$ incorporation into amino sugars (Fig. 3;
Supplemental Figure 3). Except for rosinweed, the fungal GlcN:MurN ratio in the topsoil was similar to the deepest soil layer $(340-360 \mathrm{~cm})$ with no clear decrease with depth (Supplemental Figure 4). At 220-360 $\mathrm{cm}$, the fungal GlcN:MurN ratio was higher for kernza compared to rosinweed (Supplemental Figure 4). 

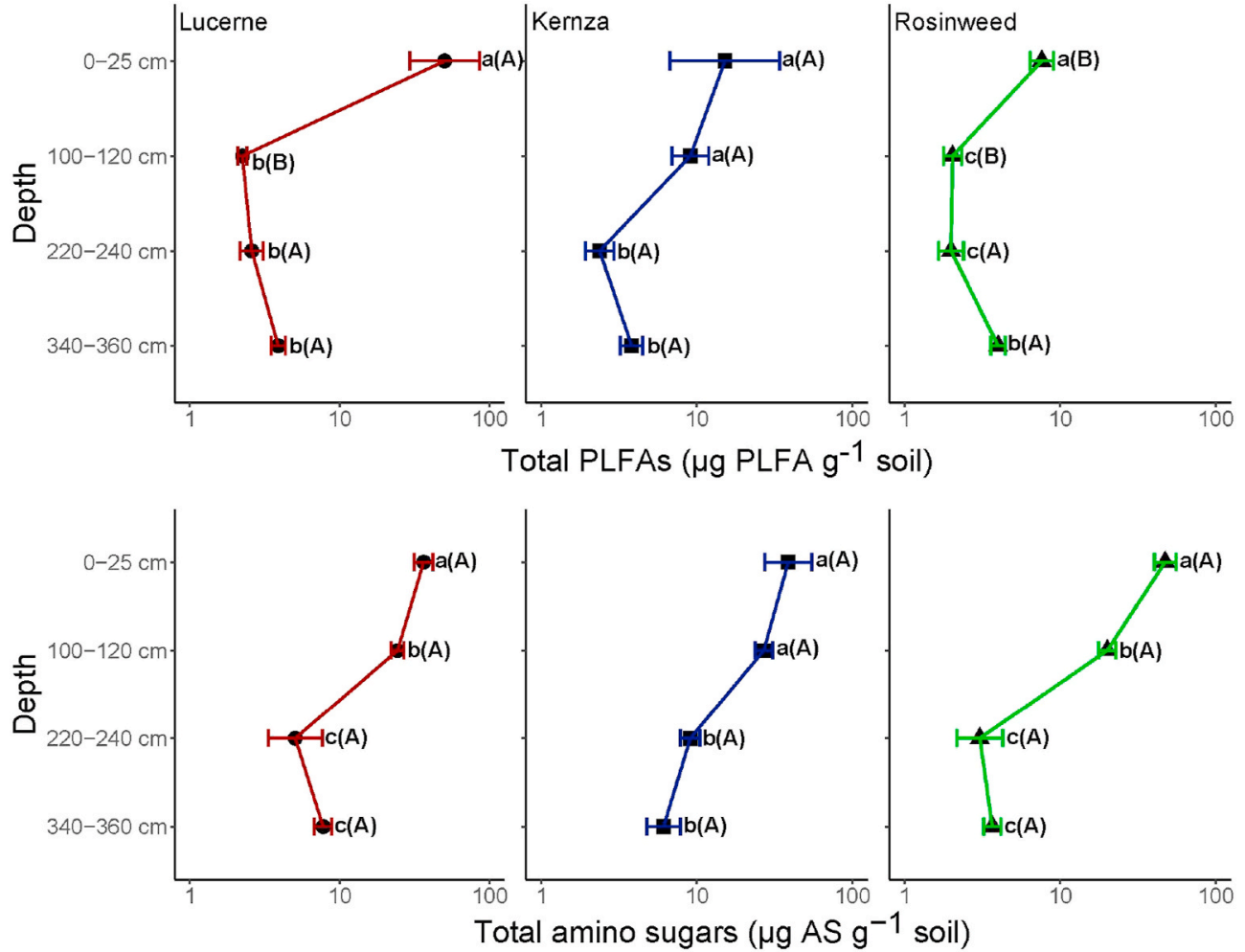

Fig. 3. Total PLFA content ( $\mu$ g PLFA $g^{-1}$ soil) and total amino sugar (AS) content ( $\mu \mathrm{g}$ AS $\mathrm{g}^{-1}$ soil) across four depth intervals: $0-25,100-120,220-240$ and $340-360 \mathrm{~cm}$ for lucerne, kernza and rosinweed. Different letters indicate statistically significant differences $(p<0.05)$ between both the total amino sugar content and total PLFA content among the depths for each plant species (lower case letters) and between plant species for each depth (upper case letters). Relative standard errors (symmetric error bars) are shown on the logarithmic plot.
3.3. Partitioning of rhizodeposited C in PLFA and amino sugar pools and relative microbial stabilization

The partitioning of rhizodeposited $C$ into PLFA and amino sugar pools declined with depth $(p=0.013 ; p=0.016$, respectively), reflecting a reduction of $\mathrm{C}$ entering the living and predominantly dead microbial pools (Fig. 4; Supplemental Table 4). Within the topsoil, there was a considerably larger partitioning of rhizodeposited $\mathrm{C}$ within both the amino sugar and PLFA pool for lucerne compared with kernza and rosinweed (Fig. 4; Supplemental Table 4). This coincides with a generally higher living biomass and amino sugar abundance within the topsoil of lucerne (Fig. 3).

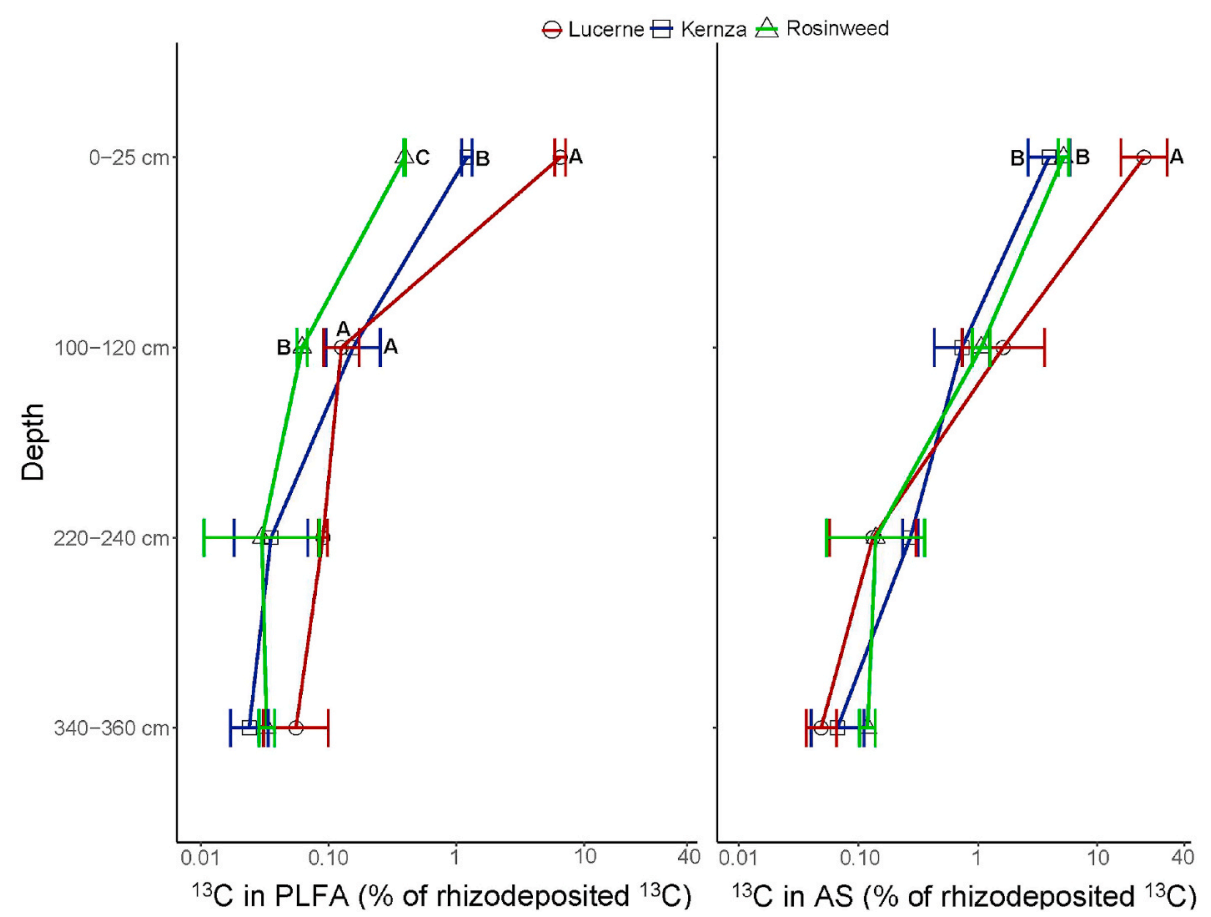

Fig. 4. Partitioned C derived from rhizodeposition into PLFA $\left({ }^{13} \mathrm{C}\right.$ in PLFA) and amino sugar $\left({ }^{13} \mathrm{C}\right.$ in AS) pools across four depth intervals: $0-25,100-120$, $220-240$ and 340-360 $\mathrm{cm}$ for lucerne, kernza and rosinweed. Different letters indicate statistically significant differences $(p<0.05)$ between the rhizodeposited $\mathrm{C}$ partitioned into PLFA and amino sugar pools among species for each depth. Relative standard errors (symmetric error bars) are shown on the logarithmic plot. 
The ratio of rhizodeposited ${ }^{13} \mathrm{C}$ in the PLFA and amino sugar pools was taken as an indicator of relative microbial stabilization, and this was $<0$ in the topsoil across all plant species showing a dominance of $\mathrm{C}$ in living microbial biomass (in the form of less stabilized C) (Fig. 5). The relative microbial stabilization was $>0$ in the subsoil across all species showing a dominance of $\mathrm{C}$ in microbial necromass (Fig. 5). The relative microbial stabilization did not vary within increasing depths from 100 to $360 \mathrm{~cm}$ or between plant species at each depth (Fig. 5).

\subsection{Rhizomicrobial community composition}

The living microbial biomass (as estimated as the sum of all PLFAs) and ${ }^{13} \mathrm{C}$ incorporation into the PLFAs of the rhizomicrobiota within the topsoil comprised all targeted microbial groups (i.e., Gram-positive, Gram-negative, fungi, and actinobacteria) across all plant species (Fig. 6). With increasing depth in the subsoil layers, there was a clear dominance of PLFA from Gram-negative bacterial and fungal groups across the three plant species (Fig. 6). Indeed, below the topsoil, there was minimal detection of Gram-positive bacteria, and actinobacteria were found almost exclusively within the topsoil across all plant species (Fig. 6).

Plant species had no clear effects on the proportions of Gramnegative, Gram-positive, and fungal microbial groups, except for a higher microbial abundance of Gram-positive and Gram-negative bacteria within the topsoil under lucerne and a lower abundance of Gramnegative bacteria under rosinweed at $100-120 \mathrm{~cm}$ (Fig. 6). Similarly, there was no effect of plant species on the ${ }^{13} \mathrm{C}$ incorporation in any microbial groups (data not shown).

\section{Discussion}

\subsection{C investment in roots and rhizodeposition}

The $\mathrm{C}$ input by roots and rhizodeposition by all plants strongly decreased with depth from more than $1 \mathrm{~g} \mathrm{C} \mathrm{kg}^{-1}$ soil in the topsoil to less than $0.1 \mathrm{~g} \mathrm{C} \mathrm{kg}^{-1}$ soil at $360 \mathrm{~cm}$ depth, i.e. a factor 10 lower of $\mathrm{C}$ input in the deep subsoil (Fig. 1; Supplemental Table 3). The ratio of net rhizodeposition $\mathrm{C}$ to SOC also decreased with depth indicating marginal contribution of rhizodeposition to SOC in subsoils (Supplemental Figure 5). Conversely, with depth, the root $\mathrm{C}$ contributed more to SOC, showing the importance of roots as a dominant $\mathrm{C}$ source in deep soil (Supplemental Figure 5).

The effects of multiple physical, chemical and biological properties on rhizodeposition have been quantified predominately in the topsoil (e. g., Kuzyakov and Domanski, 2000; de Neergaard and Gorissen, 2004; Wichern et al., 2007). Far less is known about plant C investment in rhizodeposition within subsoils. The rhizodeposition accounted for $35 \%$, $45 \%$, and $36 \%$ of the total $\mathrm{C}$ input into the topsoil layer, but declined to $8.0 \%, 2.5 \%$, and $2.7 \%$ in the deepest soil layer for lucerne, kernza, and rosinweed, respectively (Fig. 2), showing a redistribution of plant $\mathrm{C}$ investment into different functional $\mathrm{C}$ pools with depth. This corresponds to higher $\mathrm{C}$ investments in rhizodeposition in the topsoil and, in contrast, higher $\mathrm{C}$ investments in root growth in the subsoil.

In the topsoil, the higher investments in rhizodeposition could be linked with the mutualistic plant-microbial interactions within the rhizosphere (e.g., Jones et al., 2009; Czaban et al., 2018). The stimulation of rhizosphere microbes (e.g., root-associated symbionts such as mycorrhiza) is an evolutionary strategy mutually beneficial for microbes through the provisioning of labile $\mathrm{C}$ and receiving nutrients (Bais et al., 2006; Jones et al., 2004, 2009; Schmidt et al., 2019). In contrast, in the subsoil, the higher $\mathrm{C}$ investment in growth and maintenance of a deep-rooted system provides plants with the access to deep soil resources (e.g., water) when topsoil resources become scarce (Maeght et al., 2013; Pierret et al., 2016; Thorup-Kristensen et al., 2020b).

\subsection{Importance of lucerne for storage and stabilization of rhizodeposited C}

Lucerne had the greatest $\mathrm{C}$ input (both root $\mathrm{C}$ and rhizodeposited $\mathrm{C}$ ) in the deepest soil layer (340-360 cm) (Fig. 1; Supplemental Table 3).

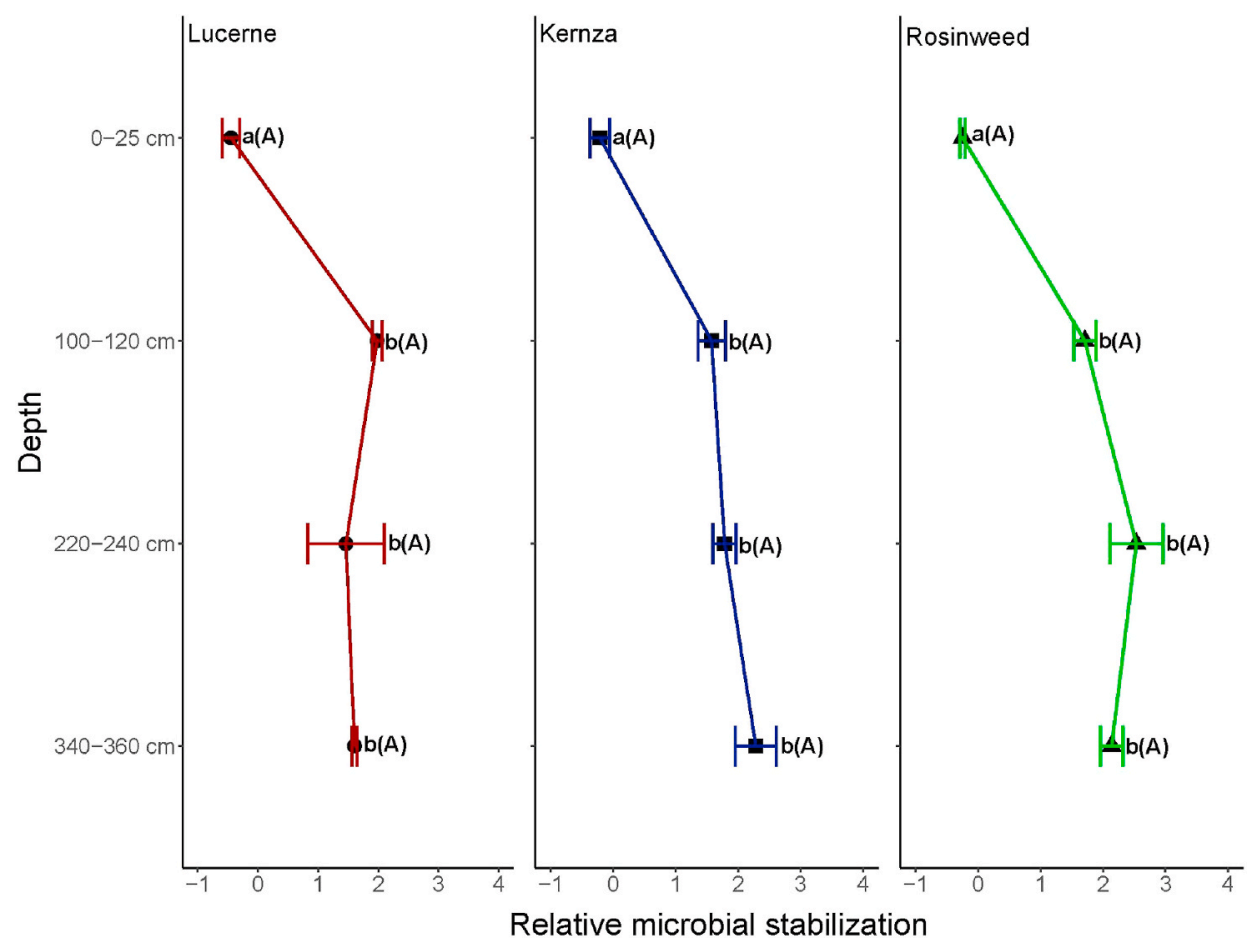

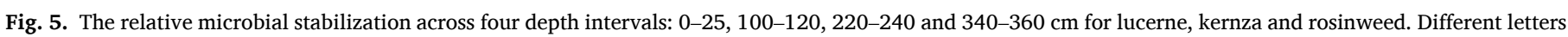

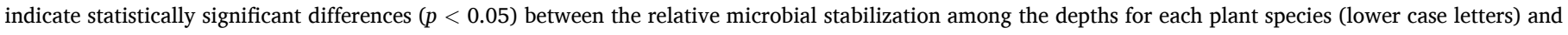
between plant species for each depth (upper case letters). 

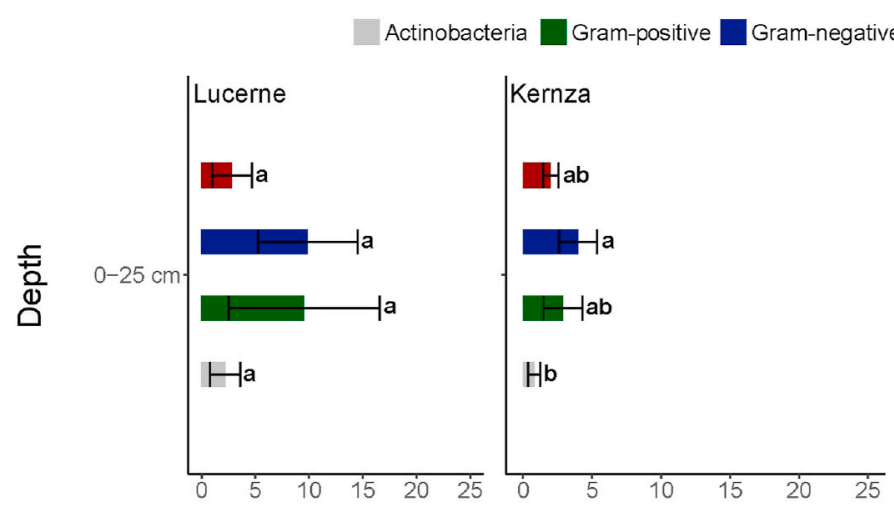

\section{fungal}
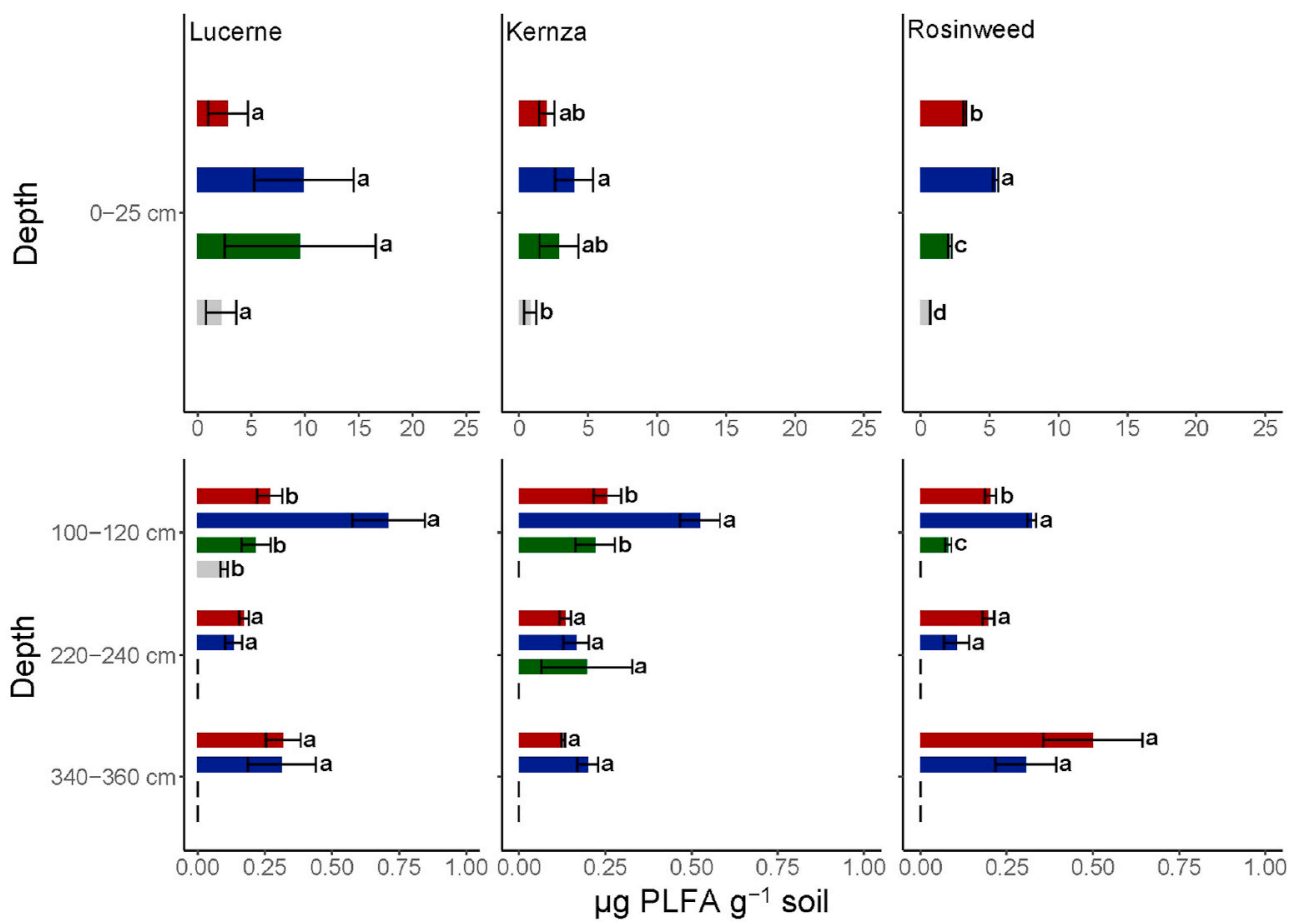

Fig. 6. The living microbial composition ( $\mu \mathrm{g}$ PLFA $g^{-1}$ soil) among the microbial groups: Actinobacteria (grey bar), Gram-positive bacteria (green bar), Gram-negative bacteria (blue bar), and fungi (red bar) at $0-25$, $100-120,220-240$ and $340-360 \mathrm{~cm}$ for lucerne, kernza, and rosinweed. Different letters indicate statistically significant differences $(p<0.05)$ between microbial groups among the depths for each plant species. Note scale differences between PLFAs in topsoil $(0-25 \mathrm{~cm}$ ) and subsoils. (For interpretation of the references to colour in this figure legend, the reader is referred to the Web version of this article.)
This is related to a greater deep rooting intensity of lucerne compared to kernza and rosinweed within these RootTowers (Dorte B. Dresb $\varnothing l$, Personal Communication). Also, under field conditions, lucerne displays rooting depths exceeding rosinweed and more root growth in deep soils compared to kernza (Corentin Clement, Personal Communication). This indicates that lucerne displays a greater capacity for $\mathrm{C}$ input in deep soil layers than both kernza and rosinweed.

Exclusively within the topsoil, there was a considerably greater partitioning of rhizodeposited C into PLFA and amino sugar pools for lucerne compared with both kernza and rosinweed (Fig. 4; Supplemental Table 4). Lucerne harbored both a larger living microbial biomass and dead microbial necromass than the non-legumes in the topsoil (Fig. 3). The $\mathrm{N}_{2}$ fixation by lucerne results in greater $\mathrm{N}$ inputs to the soil from root turnover, and the production and subsequent diffusion of more N-rich exudates such as amino acids (Fustec et al., 2010). The coupling of both $\mathrm{C}$ and $\mathrm{N}$ inputs into the topsoil under lucerne promoted the microbial biomass production and subsequent accumulation of microbial residues within the topsoil and as such a greater $\mathrm{C}$ partitioning into the microbial pools.

\subsection{Rhizomicrobial community composition}

The living microbial biomass (as estimated as the sum of all PLFAs) and ${ }^{13} \mathrm{C}$ incorporation into the PLFAs of the rhizomicrobial community generally declined with depth and differed among species within the topsoil and at 100-120 cm (Fig. 3, Supplemental Figure 1). In the subsoil, there was a dominance of both living and ${ }^{13} \mathrm{C}$ incorporation into Gram-negative bacterial and fungal groups across the rhizosphere of the three plant species (Fig. 6). The dominance of these microbial groups deviates from an expected increase in the relative abundance of Grampositive and actinobacteria with depth (e.g., Blume et al., 2002; Fierer et al., 2003; Schnecker et al., 2015; Banfield et al., 2017; Pries et al., 2018). In soil, PLFAs associated with Gram-negative bacteria have often been reported in the rhizosphere, which is a hotspot of readily available $\mathrm{C}$ in the form of dissolved low molecular weight organic compounds. In contrast, Gram-positive PLFAs have often been found in environments with rare $\mathrm{C}$ input, indicating these organisms may thrive on larger proportions of stabilized C compounds (Waldrop and Firestone, 2004; Kramer and Gleixner, 2006; Gunina et al., 2014). Thus, in the subsoil rhizosphere, the input of labile $C$ could represent a selective advantage for copiotrophic microbial communities typically represented by Gram-negative species. Indeed, it has been shown in previous studies (Griffiths et al., 1999) that higher rates of C addition to soil will raise the proportions of fungi and Gram-negative bacteria as compared with the proportions of actinobacteria and Gram-positive bacteria.

The dominant presence of fungi in deep soil layers was to some extent unexpected, since these eukaryotes are obligate aerobes and can be restricted by low oxygen availability. Yet, in soils without signs of recurrent anaerobiosis, the presence of diverse fungi at depth has previously been reported (Fierer et al., 2003; Schlatter et al., 2018). Fungi have the potential to degrade polymerized plant compounds (cellulose and lignin) due to versatile production of extracellular enzymes (Blagodatskaya et al., 2007; Fontaine et al., 2011; Bai et al., 2013). Our results indicate that fungi can contribute to aerobic carbon turnover and SOC stabilization in deep surface ecosystems with input of root carbon, although the role of fungi could have been stimulated in the present RootTower facility due to lateral diffusion of atmospheric oxygen.

\subsection{Stabilization of rhizodeposited $C$}

The partitioning of rhizodeposited C into PLFA and amino sugar pools declined with depth across all species (Fig. 4; Supplemental Table 4). This pattern could be explained by: (1) nutrient limitations and a lack of active microbes in subsoils resulting in a larger proportion of plantderived $\mathrm{C}$ left non-decomposed as compared to the topsoil ( Liang et al., 2019b) and (2) lower carbon use efficiency with depth favoring microbial catabolism, i.e., with more $\mathrm{C}$ allocated to respiration (Spohn et al., 2016).

The relative microbial stabilization was used as an indication of the relative stabilization of rhizodeposited $\mathrm{C}$ when entering the microbial biomass based on ${ }^{13} \mathrm{C}$ incorporation into the amino sugar and PLFA pool. The relative microbial stabilization can be used to compare the importance of living microbial biomass versus dead microbial necromass among treatments (i.e., different depths and plant species), but does not 
signify the absolute stability of rhizodeposition or SOC.

The relative microbial stabilization in the subsoil across all species confirmed higher microbial stabilization of rhizodeposited $\mathrm{C}$ with depth (Fig. 5). This is complimentary to the notion that microbial necromass comprise nearly $50 \%$ of SOC with proportionally higher microbialderived compounds below the topsoil (e.g., Miltner et al., 2009, 2012; Liang et al., 2011; Rumpel and Kögel-Knabner, 2011; Khan et al., 2016). The low abundance of actinobacteria, described as microbial necromass decomposers (Apostel et al., 2018) might have favored the significant accumulation of the cell wall residues in the RootTower soils. This shows that even if the absolute contribution of rhizodeposited $\mathrm{C}$ to deeper soil layers might be low, this $\mathrm{C}$ source will become stabilized, thus contributing to $\mathrm{C}$ storage over potentially long time scales.

\subsection{Role of soil conditions in the RootTowers}

It should be noted, that conditions within the RootTowers do not entirely resemble deep soil conditions, irrespective of attempts to minimize variation from field conditions in terms of soil texture, bulk density and SOC content. Differences in the temperature fluctuations and oxygen availability, for example, from field conditions all have the potential to influence the processes studied. The use of the RootTowers facilitates relatively easy access to the roots and the rhizosphere for studying deep-rooted crops and associated deep soil processes, which goes beyond the scope of traditional pot or incubation experiments. However, there is a clear need to extend studies to field conditions, where the study of processes associated with deep rooting is associated with multiple challenges, including spatial variability in soil and root conditions, difficulties in continuous monitoring, and in root and soil sampling.

\section{Conclusions}

The rhizodeposition strongly declined with depth across all plant species, corresponding to higher $\mathrm{C}$ investments in rhizodeposition in the topsoil and higher $\mathrm{C}$ investments in root growth in the subsoil. In the subsoil, the relative microbial stabilization showed a dominance of $\mathrm{C}$ allocated in microbial necromass across all plant species, and is indicative of rhizodeposited $\mathrm{C}$ stabilization in the form of microbial residues. Overall, we showed that even relatively small $\mathrm{C}$ inputs will become stabilized in deeper soil layers, and thus contribute to $\mathrm{C}$ storage. This illustrates the importance of deep-rooted crops for $C$ input in deep soil, and it suggests some potential in the use of deep-rooted crops (specifically lucerne) in storing $\mathrm{C}$ in deep subsoils.

\section{Declaration of competing interest}

The authors declare that they have no known competing financial interests or personal relationships that could have appeared to influence the work reported in this paper.

\section{Acknowledgements}

We thank Kirsten Enggrob for discussions, Karin Dyrberg and Bodil Stensgaard for technical assistance, and Dorte Bodin Dresbøll and Kristian Thorup-Kristensen for providing access to the RootTower facility. We further acknowledge Jens Dyckmans and the whole team at the Stable Isotope Laboratory of Goettingen University. This work was performed as part of the Deep Frontier project, which is a research collaboration between University of Copenhagen, Aarhus University and International Centre for Research in Organic Food Systems (ICROFS), financed by the Villum Foundation. The work was further supported by the "Stable or fertile - solving the soil C-N dilemma by exploiting the legume rhizosphere" project funded by the Danish Independent Research Fund (project no. 9041-00132 A).

\section{Appendix A. Supplementary data}

Supplementary data to this article can be found online at https://doi. org/10.1016/j.soilbio.2020.108008.

\section{References}

Amelung, W., Miltner, A., Zhang, X., Zech, W., 2001. Fate of microbial residues during litter decomposition as affected by minerals. Soil Science 166, 598-606.

Apostel, C., Herschbach, J., Bore, E.K., Spielvogel, S., Kuzyakov, Y., Dippold, M.A., 2018. Food for microorganisms: position-specific ${ }^{13} \mathrm{C}$ labeling and ${ }^{13} \mathrm{C}-\mathrm{PLFA}$ analysis reveals preferences for sorbed or necromass C. Geoderma 312, 86-94.

Bai, Z., Bodé, S., Huygens, D., Zhang, X., Boeckx, P., 2013. Kinetics of amino sugar formation from organic residues of different quality. Soil Biology and Biochemistry 57, 814-821.

Bai, Z., Ma, Q., Dai, Y., Yuan, H., Ye, J., Yu, W., 2017. Spatial heterogeneity of SOM concentrations associated with white-rot versus brown-rot wood decay. Scientific Reports 7, 13758.

Bais, H.P., Weir, T.L., Perry, L.G., Gilroy, S., Vivanco, J.M., 2006. The role of root exudates in rhizosphere interactions with plants and other organisms. Annual Review of Plant Biology 57, 233-266.

Banfield, C.C., Dippold, M.A., Pausch, J., Hoang, D.T., Kuzyakov, Y., 2017. Biopore history determines the microbial community composition in subsoil hotspots. Biology and Fertility of Soils 53, 573-588.

Bell, J.M., Smith, J.L., Bailey, V.L., Bolton, H., 2003. Priming effect and C storage in semi-arid no-till spring crop rotations. Biology and Fertility of Soils 37, 237-244.

Blagodatskaya, E.V., Blagodatsky, S.A., Anderson, T.H., Kuzyakov, Y., 2007. Priming effects in Chernozem induced by glucose and $\mathrm{N}$ in relation to microbial growth strategies. Applied Soil Ecology 37, 95-105.

Bligh, E.G., Dyer, W.J., 1959. A rapid method of total lipid extraction and purification. Canadian Journal of Biochemistry and Physiology 37, 911-917.

Blume, E., Bischoff, M., Reichert, J.M., Moorman, T., Konopka, A., Turco, R.F., 2002. Surface and subsurface microbial biomass, community structure and metabolic activity as a function of soil depth and season. Applied Soil Ecology 20, 171-181.

Conover, W.J., Johnson, M.E., Johnson, M.M., 1981. A comparative study of tests for homogeneity of variances, with applications to the outer continental shelf bidding data. Technometrics 23, 351-361.

Czaban, W., Rasmussen, J., Laursen, B.B., Vidkjær, N.H., Sapkota, R., Nicolaisen, M., Fomsgaard, I.S., 2018. Multiple effects of secondary metabolites on amino acid cycling in white clover rhizosphere. Soil Biology and Biochemistry 123, 54-63.

de Neergaard, A., Gorissen, A., 2004. Carbon allocation to roots, rhizodeposits and soil after pulse labelling: a comparison of white clover (Trifolium repens L.) and perennial ryegrass (Lolium perenne L.). Biology and Fertility of Soils 39, 228-234.

Dippold, M.A., Boesel, S., Gunina, A., Kuzyakov, Y., Glaser, B., 2014. Improved $\delta^{13} \mathrm{C}$ analysis of amino sugars in soil by ion chromatography-oxidation-isotope ratio mass spectrometry. Rapid Communications in Mass Spectrometry 28, 569-576.

Dungait, J.A.J., Kemmitt, S.J., Michallon, L., Guo, S., Wen, Q., Brookes, P.C., Evershed, R.P., 2011. Variable responses of the soil microbial biomass to trace concentrations ofC-labelled glucose, using C-PLFA analysis. European Journal of Soil Science 62, 117-126.

Engelking, B., Flessa, H., Joergensen, R.G., 2007. Shifts in amino sugar and ergosterol contents after addition of sucrose and cellulose to soil. Soil Biology and Biochemistry 39, 2111-2118.

Faust, S., Heinze, S., Ngosong, C., Sradnick, A., Oltmanns, M., Raupp, J., Geisseler, D., Joergensen, R.G., 2017. Effect of biodynamic soil amendments on microbial communities in comparison with inorganic fertilization. Applied Soil Ecology 114, 82-89.

Fierer, N., Schimel, J.P., Holden, P.A., 2003. Variations in microbial community composition through two soil depth profiles. Soil Biology and Biochemistry 35, 167-176.

Fontaine, S., Hénault, C., Aamor, A., Bdioui, N., Bloor, J.M.G., Maire, V., Mary, B., Revaillot, S., Maron, P.A., 2011. Fungi mediate long term sequestration of carbon and nitrogen in soil through their priming effect. Soil Biology and Biochemistry 43, 86-96.

Frostegård, A., Bååth, E., Tunlid, A., 1993. Shifts in the structure of soil microbial communities in limed forests as revealed by phospholipid fatty acid analysis. Soil Biology and Biochemistry 25, 723-730.

Frostegård, Å., Bååth, E., 1996. The use of phospholipid fatty acid analysis to estimate bacterial and fungal biomass in soil. Biology and Fertility of Soils 22, 59-65.

Fustec, J., Lesuffleur, F., Mahieu, S., Cliquet, J.B., 2010. Nitrogen rhizodeposition of legumes. A review, 30. Agronomy for Sustainable Development, pp. 57-66.

Glaser, B., Turrión, M.B., Alef, K., 2004. Amino sugars and muramic acid-biomarkers for soil microbial community structure analysis. Soil Biology and Biochemistry 36, 399-407.

Glaser, B., Gross, S., 2005. Compound-specific $\delta$ C analysis of individual amino sugars-a tool to quantify timing and amount of soil microbial residue stabilization. Rapid Communications in Mass Spectrometry 19, 1409-1416.

Griffiths, B.S., Ritz, K., Ebblewhite, N., Dobson, G., 1999. Soil microbial community structure: effects of substrate loading rates. Soil Biology and Biochemistry 31, $145-153$.

Gunina, A., Dippold, M.A., Glaser, B., Kuzyakov, Y., 2014. Fate of low molecular weight organic substances in an arable soil: from microbial uptake to utilisation and stabilisation. Soil Biology and Biochemistry 77, 304-313. 
Gunina, A., Dippold, M., Glaser, B., Kuzyakov, Y., 2017. Turnover of microbial groups and cell components in soil: C analysis of cellular biomarkers. Biogeosciences 14, $271-283$.

Hafner, S., Kuzyakov, Y., 2016. Carbon input and partitioning in subsoil by chicory and alfalfa. Plant and Soil 406, 29-42.

IUSS Working Group WRB, 2015. World Reference Base for Soil Resources 2014, Update 2015 International Soil Classification System for Naming Soils and Creating Legends for Soil Maps. In: World Soil Resources Reports No. 106. FAO, Rome.

Joergensen, R.G., 2018. Amino sugars as specific indices for fungal and bacterial residues in soil. Biology and Fertility of Soils 54, 559-568.

Jones, D.L., Hodge, A., Kuzyakov, Y., 2004. Plant and mycorrhizal regulation of rhizodeposition. New Phytologist 163, 459-480.

Jones, D.L., Nguyen, C., Finlay, R.D., 2009. Carbon flow in the rhizosphere: carbon trading at the soil-root interface. Plant and Soil 321, 5-33.

Kell, D.B., 2011. Breeding crop plants with deep roots: their role in sustainable carbon, nutrient and water sequestration. Annals of Botany 108, 407-418.

Kell, D.B., 2012. Large-scale sequestration of atmospheric carbon via plant roots in natural and agricultural ecosystems: why and how. Philosophical Transactions of the Royal Society B: Biological Sciences 367, 1589-1597.

Khan, K.S., Mack, R., Castillo, X., Kaiser, M., Joergensen, R.G., 2016. Microbial biomass, fungal and bacterial residues, and their relationships to the soil organic matter C/N/ $\mathrm{P} / \mathrm{S}$ ratios. Geoderma 271, 115-123.

Kindler, R., Miltner, A., Thullner, M., Richnow, H.H., Kästner, M., 2009. Fate of bacterial biomass derived fatty acids in soil and their contribution to soil organic matter. Organic Geochemistry 40, 29-37.

Kramer, C., Gleixner, G., 2006. Variable use of plant-and soil-derived carbon by microorganisms in agricultural soils. Soil Biology and Biochemistry 38, 3267-3278.

Kušlienè, G., Rasmussen, J., Kuzyakov, Y., Eriksen, J., 2014. Medium-term response of microbial community to rhizodeposits of white clover and ryegrass and tracing of active processes induced by $\mathrm{C}$ and $\mathrm{N}$ labelled exudates. Soil Biology and Biochemistry 76, 22-33.

Kuzyakov, Y., Domanski, G., 2000. Carbon input by plants into the soil. Review. Journa of Plant Nutrition and Soil Science 163, 421-431.

Lal, R., Negassa, W., Lorenz, K., 2015. Carbon sequestration in soil. Current Opinion in Environmental Sustainability 15, 79-86.

Liang, C., Cheng, G., Wixon, D.L., Balser, T.C., 2011. An Absorbing Markov chain approach to understanding the microbial role in soil carbon stabilization. Biogeochemistry 106, 303-309.

Liang, C., Schimel, J.P., Jastrow, J.D., 2017. The importance of anabolism in microbial control over soil carbon storage. Nature Microbiology 2, 1-6.

Liang, Z., Elsgaard, L., Nicolaisen, M.H., Lyhne-Kjærbye, A., Olesen, J.E., 2018. Carbon mineralization and microbial activity in agricultural topsoil and subsoil as regulated by root nitrogen and recalcitrant carbon concentrations. Plant and Soil 433, 65-82.

Liang, C., Amelung, W., Lehmann, J., Kästner, M., 2019a. Quantitative assessment of microbial necromass contribution to soil organic matter. Global Change Biology 25, 3578-3590.

Liang, Z., Olesen, J.E., Jensen, J.L., Elsgaard, L., 2019b. Nutrient availability affects carbon turnover and microbial physiology differently in topsoil and subsoil under a temperate grassland. Geoderma 336, 22-30.

Maeght, J.L., Rewald, B., Pierret, A., 2013. How to study deep roots-and why it matters. Frontiers in Plant Science 4, 299.

Miltner, A., Kindler, R., Knicker, H., Richnow, H.H., Kästner, M., 2009. Fate of microbial biomass-derived amino acids in soil and their contribution to soil organic matter. Organic Geochemistry 40, 978-985.

Miltner, A., Bombach, P., Schmidt-Brücken, B., Kästner, M., 2012. SOM genesis: microbial biomass as a significant source. Biogeochemistry 111, 41-55.

Pausch, J., Kuzyakov, Y., 2018. Carbon input by roots into the soil: quantification of rhizodeposition from root to ecosystem scale. Global Change Biology 24, 1-12.

Pedersen, I.F., Sørensen, P., Rasmussen, J., Withers, P.J., Rubæk, G.H., 2019. Fertilizer ammonium: nitrate ratios determine phosphorus uptake by young maize plants. Journal of Plant Nutrition and Soil Science 182, 541-551.

Petersen, S.O., Frohne, P.S., Kennedy, A.C., 2002. Dynamics of a soil microbial community under spring wheat. Soil Science Society of America Journal 66, 826-833.
Pierret, A., Maeght, J.L., Clément, C., Montoroi, J.P., Hartmann, C., Gonkhamdee, S., 2016. Understanding deep roots and their functions in ecosystems: an advocacy for more unconventional research. Annals of Botany 118, 621-635.

Pries, C.E.H., Sulman, B.N., West, C., O'Neill, C., Poppleton, E., Porras, R.C., Castanha, C., Zhu, B., Wiedemeier, D.B., Torn, M.S., 2018. Root litter decomposition slows with soil depth. Soil Biology and Biochemistry 125, 103-114.

Ramnarine, R., Voroney, R.P., Wagner-Riddle, C., Dunfield, K.E., 2011. Carbonate removal by acid fumigation for measuring the $\delta \mathrm{C}$ of soil organic carbon. Canadian Journal of Soil Science 91, 247-250.

Rasmussen, C.R., Thorup-Kristensen, K., Dresbøll, D.B., 2020. Uptake of subsoil water below $2 \mathrm{~m}$ fails to alleviate drought response in deep-rooted Chicory (Cichorium intybus L.). Plant and Soil 446, 275-290.

Rasmussen, J., Kusliene, G., Jacobsen, O.S., Kuzyakov, Y., Eriksen, J., 2013. Bicarbonate as tracer for assimilated $\mathrm{C}$ and homogeneity of $\mathrm{C}$ and $\mathrm{N}$ distribution in plants by alternative labeling approaches. Plant and Soil 371, 191-198.

Rasmussen, J., Gylfadóttir, T., Dhalama, N.R., De Notaris, C., Kätterer, T., 2019. Temporal fate of $\mathrm{N}$ and $\mathrm{C}$ leaf-fed to red and white clover in pure stand or mixture with grass - implications for estimation of legume derived $\mathrm{N}$ in soil and companion species. Soil Biology and Biochemistry 133, 60-71.

Royston, J.P., 1982. An extension of Shapiro and Wilk's W test for normality to large samples. Journal of the Royal Statistical Society: Series C (Applied Statistics) 31, 115-124.

Rumpel, C., Kögel-Knabner, I., 2011. Deep soil organic matter —a key but poorly understood component of terrestrial C cycle. Plant and Soil 338, 143-158.

R Core Team, 2018. R: A Language and Environment for Statistical Computing. R Foundation for Statistical Computing, Vienna, Austria. URL. https://www.R-project. org/.

Salomé, C., Nunan, N., Pouteau, V., Lerch, T.Z., Chenu, C., 2010. Carbon dynamics in topsoil and in subsoil may be controlled by different regulatory mechanisms. Global Change Biology 16, 416-426.

Sanaullah, M., Chabbi, A., Leifeld, J., Bardoux, G., Billou, D., Rumpel, C., 2011. Decomposition and stabilization of root litter in top-and subsoil horizons: what is the difference? Plant and Soil 338, 127-141.

Schlatter, D.C., Yin, C., Burke, I., Hulbert, S., Paulitz, T., 2018. Location, root proximity, and glyphosate-use history modulate the effects of glyphosate on fungal community networks of wheat. Microbial Ecology 76, 240-257.

Schmidt, R., Ulanova, D., Wick, L.Y., Bode, H.B., Garbeva, P., 2019. Microbe-driven chemical ecology: past, present and future. The ISME Journal 13, 2656-2663.

Schnecker, J., Wild, B., Takriti, M., Alves, R.J.E., Gentsch, N., Gittel, A., Hofer, A., Klaus, K., Knoltsch, A., Lashchinskiy, N., Mikutta, R., 2015. Microbial community composition shapes enzyme patterns in topsoil and subsoil horizons along a latitudinal transect in Western Siberia. Soil Biology and Biochemistry 83, 106-115.

Spohn, M., Klaus, K., Wanek, W., Richter, A., 2016. Microbial carbon use efficiency and biomass turnover times depending on soil depth-Implications for carbon cycling. Soil Biology and Biochemistry 96, 74-81.

Stockmann, U., Adams, M.A., Crawford, J.W., Field, D.J., Henakaarchchi, N., Jenkins, M., Minasny, B., McBratney, A.B., De Courcelles, V.D.R., Singh, K., Wheeler, I., 2013. The knowns, known unknowns and unknowns of sequestration of soil organic carbon. Agriculture, Ecosystems \& Environment 164, 80-99.

Thorup-Kristensen, K., Halberg, N., Nicolaisen, M.H., Olesen, J.E., Dresbøll, D.B., 2020a. Exposing deep roots: a rhizobox laboratory. Trends in Plant Science 25, 418-419.

Thorup-Kristensen, K., Halberg, N., Nicolaisen, M., Olesen, J.E., Crews, T.E., Hinsinger, P., Kirkegaard, J., Pierret, A., Dresbøll, D.B., 2020b. Digging deeper for agricultural resources, the value of deep rooting. Trends in Plant Science 25, 406-417.

Waldrop, M.P., Firestone, M.K., 2004. Microbial community utilization of recalcitrant and simple carbon compounds: impact of oak-woodland plant communities. Oecologia 138, 275-284.

Wichern, F., Mayer, J., Joergensen, R.G., Müller, T., 2007. Rhizodeposition of C and N in peas and oats after $\mathrm{C}^{-15} \mathrm{~N}$ double labelling under field conditions. Soil Biology and Biochemistry 39, 2527-2537.

Zhang, X., Amelung, W., 1996. Gas chromatographic determination of muramic acid, glucosamine, mannosamine, and galactosamine in soils. Soil Biology and Biochemistry 28, 1201-1206. 